\title{
Empirical Study on Volatility of RMB against US Dollar Based on ARCH Family Model
}

\author{
Yudong Wu \\ School of Basic Science, Harbin University of Commerce, Harbin 150028, China \\ E-mail:wuyudong@aliyun.com
}

Keywords: RMB Exchange Rate; Volatility; ARCH Family Model; Heteroscedasticity Test

\begin{abstract}
Based on the daily data of the central parity of the RMB against the US dollar from August 2015 to March 2017, this paper uses the ARCH model as the main research tool and through corresponding tests to establish the ARCH model of the yield rate of the exchange rate of RMB against the US dollar, thereby studying its volatility. The empirical analysis shows that the fluctuation of the RMB exchange rate does not obey the normal distribution, and the RMB exchange rate bears the significant characteristics of a sharp peak and a thick tail. In addition, through the establishment of the EGARCH model, this paper concludes that there is a certain leverage effect on the yield rate of the exchange rate of RMB against the US dollar, that is, the impact of bull news on the RMB exchange rate will be greater than the bear news. At the same time, this paper also finds that the relationship between the yield rate of the exchange rate of RMB against the US dollar and its lagging terms is not significant, which shows that the exchange rate of RMB against the US dollar is not only effective for the market, but also has a certain degree for the effectiveness of China's exchange rate reform.
\end{abstract}

\section{Introduction}

In recent years, China's economy has developed rapidly and received increasing attention from the international community. It's well known that foreign exchange is a link connecting the economies of various countries. Therefore, the RMB exchange rate has also received increasing attention from people of all countries. The exchange rate, as an important part of the price system, will affect the relative price of the country's import and export commodities, which in turn will exert important impact on the country's foreign trade. Therefore, studying the volatility of the RMB exchange rate is of great significance to the economic development of various countries.

\section{The Establishment of the Volatility Mean Model of RMB Against the US Dollar}

This paper makes an analysis of 405 data from the daily data of the central parity of the RMB against the US dollar from August 3, 2015 to March 31, 2017 and the daily exchange rate of the central parity of the RMB against the US dollar is expressed by XX. In order to improve the accuracy of the calculation, the logarithmic yield rate is multiplied by 100 so as to obtain the logarithmic yield rate of RMB against the US dollar. The specific formula can be expressed as:

$$
\mathrm{lpL}=100 \cdot\left(\ln p_{t}-\ln p_{t-1}\right)
$$

Fluctuations of the yield rate will change over time and demonstrate heteroscedasticity with "fluctuating clusters". In addition, there may be an ARCH effect, which can be shown in Figure $1^{[1]}$. 


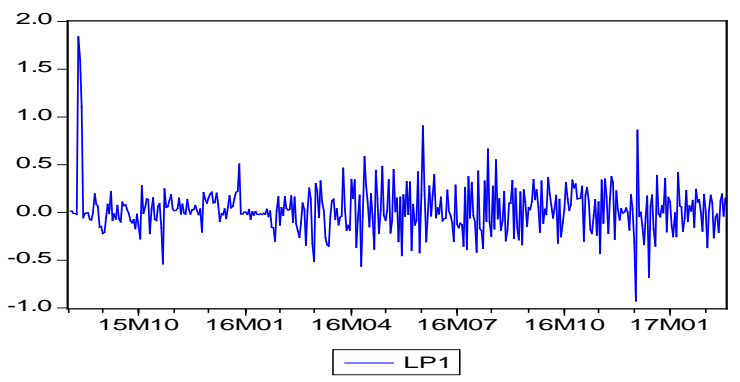

Fig 1 The time series of the yield rate of the exchange rate of RMB against the US dollar

Using the unit root method to test the stability of the logarithmic yield rate of the exchange rate of the US dollar against RMB, it's found that the yield rate series of the exchange rate all show stationary characteristics. In addition, the autocorrelation and partial autocorrelation of the sequence were inspected with the results showing in Figure 2.

Correlogram of LP1

\begin{tabular}{|c|c|c|c|c|c|c|c|}
\hline \multicolumn{8}{|c|}{$\begin{array}{l}\text { Date: } 05 / 18 / 17 \text { Time } 17=45 \\
\text { Sample: 8no3rzo15 } 2 / 1 / 2017 \\
\text { Included olbservations: } 404\end{array}$} \\
\hline Autocorrelation & Partial & Correlation & & AC & PAC & a-stat & Pralo \\
\hline 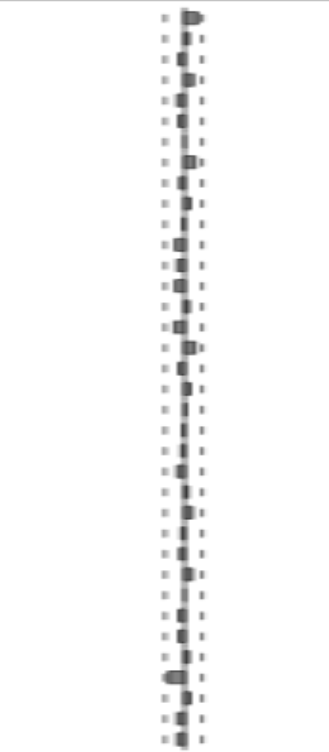 & & 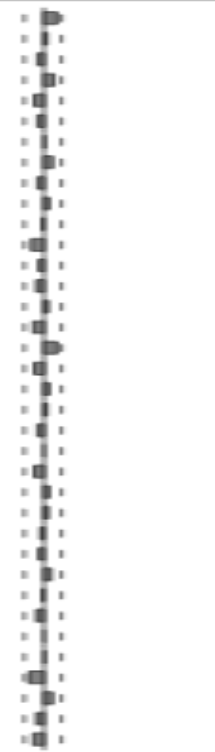 & $\begin{array}{l}1 \\
2 \\
4 \\
5 \\
6 \\
7 \\
8 \\
9 \\
10 \\
11 \\
12 \\
13 \\
14 \\
15 \\
16 \\
17 \\
18 \\
19 \\
20 \\
21 \\
22 \\
23 \\
24 \\
26 \\
27 \\
28 \\
29 \\
30 \\
31 \\
32 \\
33 \\
34 \\
35 \\
36\end{array}$ & $\begin{array}{r}0.082 \\
0.027 \\
-0.028 \\
0.055 \\
-0.040 \\
-0.029 \\
0.000 \\
0.061 \\
-0.020 \\
0.035 \\
-0.001 \\
-0.048 \\
-0.038 \\
-0.044 \\
\text { 0.026 } \\
-0.056 \\
0.065 \\
-0.027 \\
0.040 \\
0.0128 \\
-0.016 \\
-0.038 \\
0.018 \\
0.044 \\
-0.013 \\
-0.017 \\
0.046 \\
0.002 \\
-0.030 \\
-0.026 \\
0.026 \\
-0.083 \\
0.040 \\
-0.035 \\
-0.038\end{array}$ & $\begin{array}{r}0.082 \\
\text { O.021 } \\
-0.032 \\
0.060 \\
-0.048 \\
-0.026 \\
\text { O.011 } \\
0.056 \\
-0.027 \\
\text {-0.038 } \\
-0.005 \\
-0.069 \\
-0.019 \\
-0.040 \\
-0.053 \\
0.075 \\
-0.042 \\
0.035 \\
0.023 \\
-0.025 \\
\text {-0.002 } \\
-0.044 \\
0.035 \\
0.028 \\
-0.014 \\
-0.024 \\
0.045 \\
-0.005 \\
-0.035 \\
0.003 \\
0.009 \\
-0.076 \\
\text { 0.052 } \\
-0.040 \\
-0.056\end{array}$ & $\begin{array}{l}2.7115 \\
3.0118 \\
3.3364 \\
4.5684 \\
5.2313 \\
5.5710 \\
5.5710 \\
7-1103 \\
7.7747 \\
7-7794 \\
8.7542 \\
9.3599 \\
10.162 \\
10.437 \\
11.553 \\
13.562 \\
13.870 \\
14.555 \\
14.614 \\
14.638 \\
14.747 \\
15.366 \\
15.510 \\
16.340 \\
16.409 \\
16.539 \\
17.455 \\
17.458 \\
17.854 \\
18.156 \\
18.443 \\
21.490 \\
22.196 \\
22.740 \\
23.394\end{array}$ & 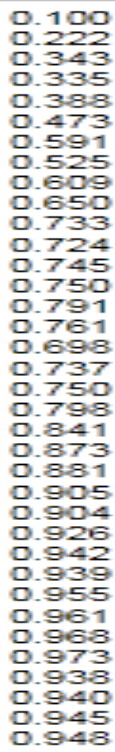 \\
\hline
\end{tabular}

Fig 2 Autocorrelation and partial autocorrelation of RMB against US dollar

By comparing the data like AIC and BIC, maximum likelihood value and the goodness of fit, the mean model of ARMA $(1,1)$ was finally selected, as shown in Table 1.

Table 1 Parameter estimation and test results of ARMA(1,1) model of sequence

\begin{tabular}{lrlll}
\hline \hline \multicolumn{1}{c}{ Variable } & Coefficient & Std. Error & t-Statistic & Prob. \\
\hline \hline \multicolumn{1}{c}{ AR(1) } & 0.406591 & 0.436779 & 0.930885 & 0.3525 \\
MA(1) & -0.316001 & 0.453550 & -0.696727 & 0.4864 \\
\hline \hline R-squared & -0.004265 & Mean dependent var & 0.029835 \\
Adjusted R-squared & -0.006770 & S.D. dependent var & 0.251154 \\
S.E. of regression & 0.252003 & Akaike info criterion & 0.086195 \\
Sum squared resid & 25.46562 & Schwarz criterion & 0.106041 \\
Log likelihood & -15.36836 & Durbin-Watson stat & 1.998213 \\
\hline \hline Inverted AR Roots & -41 & & & \\
Inverted MA Roots & -32 & & & \\
\hline \hline
\end{tabular}

$$
r_{t}=0.406591 r_{t-1}+\varepsilon_{t}-0.316001 \varepsilon_{t-1}
$$

In the following step, an ARCH-LM test is performed on the residual term of the mean model to investigate whether there is an ARCH effect ${ }^{[2]}$. 
Table 2 The mean model of the exchange rate of RMB against the US dollar ARCH-LM test

ARCH Test:

\begin{tabular}{llll}
\hline \hline F-statistic & 54.94136 & Probability & 0.000000 \\
Obs*R-squared & 86.75817 & Probability & 0.000000 \\
\hline \hline
\end{tabular}

The test results in Table 2 show that there is a significant correlation between the residual sequence in the model of the yield rate series of the exchange rate of RMB against the US dollar, that is, the ARCH effect exists. In order to eliminate the ARCH effect, it is necessary to establish the ARCH model to study the volatility of the yield rate of the exchange rate of RMB against the US dollar.

\section{The Establishment of ARCH Family Model of Volatility of RMB Against US Dollar Exchange Rate}

In order to eliminate heteroscedasticity, the ARCH model was introduced. After comparing various test indicators, it's found that the second-order ARCH model can be used to eliminate the $\mathrm{ARCH}$ effect ${ }^{[3]}$. Therefore, as for the selection of the logarithmic yield rate series, the ARCH(2) model is adopted. Based on the above mentioned analysis, the estimated results of the ARMA(1,1)-ARCH(2) model are:

Table $3 \mathrm{ARCH}(2)$ model parameter estimation and test results

\begin{tabular}{|c|c|c|c|c|}
\hline & Coefficient & Std Error & z-Statistic & Prob \\
\hline $\begin{array}{l}\text { AR(1) } \\
M A(1)\end{array}$ & $\begin{array}{r}\text { o.860341 } \\
-0.890276\end{array}$ & $\begin{array}{l}\text { o.046950 } \\
\text { o.032366 }\end{array}$ & $\begin{array}{r}18.32469 \\
-27.50615\end{array}$ & $\begin{array}{l}\text { o.oooo } \\
\text { o.oooo }\end{array}$ \\
\hline \multicolumn{5}{|c|}{ Variance Equation } \\
\hline $\begin{array}{l}C \\
\text { RESID }(-1)^{n} 2 \\
\text { RESID }(-2)^{n} 2\end{array}$ & $\begin{array}{l}\text { o.025760 } \\
0.430137 \\
0.224590\end{array}$ & $\begin{array}{l}\text { o.003223 } \\
\text { o.095980 } \\
\text { o.065527 }\end{array}$ & $\begin{array}{l}7.992742 \\
4.481534 \\
3.427430\end{array}$ & $\begin{array}{l}\text { o.0000 } \\
\text { o.0000 } \\
\text { o.0006 }\end{array}$ \\
\hline $\begin{array}{l}\text { R-squared } \\
\text { Adjusted R-squared } \\
\text { S.E. of regression } \\
\text { Sum squared resid } \\
\text { Log likelihood }\end{array}$ & $\begin{array}{l}\text { o.031482 } \\
\text { o.021748 } \\
0.248408 \\
24.55917 \\
32.96262\end{array}$ & \multicolumn{2}{|c|}{$\begin{array}{l}\text { Mean dependent var } \\
\text { S.D. dependent var } \\
\text { Akaike info criterion } \\
\text { Schwarz criterion } \\
\text { Durbin-Watson stat }\end{array}$} & $\begin{array}{r}0.029835 \\
0.251154 \\
-0.138772 \\
-0.089158 \\
1.843232\end{array}$ \\
\hline $\begin{array}{l}\text { Inverted AR Roots } \\
\text { Inverted MA Roots }\end{array}$ & $\begin{array}{l}-86 \\
-89\end{array}$ & & & \\
\hline
\end{tabular}

The resulting equation is:

$$
\begin{gathered}
r_{t}=0.860341 r_{t-1}-0.890276 \varepsilon_{t-1}+\varepsilon_{t} \\
\varepsilon_{t}^{2}=0.025760+0.430137 \varepsilon_{t-1}^{2}+0.224590 \varepsilon_{t-2}^{2}
\end{gathered}
$$

Next, the ARCH-LM test is to test the ARCH effect on the residual difference and the square sequence of the residual difference using the ARCH-LM test method, as shown in Table 4. The results show that there is no ARCH effect in the sequence, and the ARCH effect of the square sequence of the residual difference has also been eliminated. Therefore, the results prove that the established ARCH model is suitable ${ }^{[4]}$.

Table 4 The results of ARCH-LM effect test of ARCH (2) model ARCH Test:

\begin{tabular}{llll}
\hline \hline F-statistic & 0.410177 & Probability & 0.522247 \\
Obs*R-squared & 0.411805 & Probability & 0.521055 \\
\hline \hline
\end{tabular}

Taking consideration of the fact there does have information asymmetry and leverage effect in the fact of the exchange rate of the RMB against the US dollar. Moreover, in view of the impact of the RMB against the US dollar, the bear news will be greater than the bull news and investors will be more sensitive to bull news, which is consistent with the leverage effect usually found in the 
exchange rate market ${ }^{[5]}$. Therefore, the EGARCH model of the yield rate series of the exchange rate of the US dollar against RMB was carried out. After making analysis and comparison, the EGARCH $(1,1)$ model was finally established, as shown in Table 5.

Table 5 Parameter estimation and test results of EGARCH $(1,1)$ model

\begin{tabular}{|c|c|c|c|c|}
\hline & Coefficient & Std. Error & z-Statistic & Prob. \\
\hline $\begin{array}{l}A R(1) \\
M A(1)\end{array}$ & $\begin{array}{r}0.832002 \\
-0.852280\end{array}$ & $\begin{array}{l}0.051964 \\
0.039067\end{array}$ & $\begin{array}{r}16.01127 \\
-21.81612\end{array}$ & $\begin{array}{l}\text { o-oooo } \\
\text { o-oooo }\end{array}$ \\
\hline \multicolumn{5}{|c|}{ Variance Equation } \\
\hline $\begin{array}{l}c(3) \\
c(4) \\
c(5) \\
c(6)\end{array}$ & $\begin{array}{r}-0.690229 \\
0.511037 \\
-0.197545 \\
0.901431\end{array}$ & $\begin{array}{l}\text { o.097952 } \\
\text { o.059977 } \\
\text { o.038029 } \\
0.024513\end{array}$ & $\begin{array}{r}-7.046591 \\
8.520576 \\
-5.194537 \\
36.77379\end{array}$ & $\begin{array}{l}\text { O-oooo } \\
\text { o-oooo } \\
\text { o-ooooo } \\
\text { o-oooo }\end{array}$ \\
\hline $\begin{array}{l}\text { R-squared } \\
\text { Adjusted R-squared } \\
\text { S.E. of regression } \\
\text { Sum squared resid } \\
\text { Log likelihood }\end{array}$ & $\begin{array}{l}0.024849 \\
0.012568 \\
0.249571 \\
24.72735 \\
59.85267\end{array}$ & \multicolumn{2}{|c|}{$\begin{array}{l}\text { Mean dependent var } \\
\text { S.D. dependent var } \\
\text { Akaike info criterion } \\
\text { Schwarz criterion } \\
\text { Durbin-Watson stat }\end{array}$} & $\begin{array}{r}0.029835 \\
0.251154 \\
-0.267259 \\
-0.207721 \\
1.848923\end{array}$ \\
\hline $\begin{array}{l}\text { Inverted AR Roots } \\
\text { Inverted MA Roots }\end{array}$ & $\begin{array}{l}-83 \\
-85\end{array}$ & & & \\
\hline
\end{tabular}

That is, the model of the rate of return sequence of the RMB exchange rate against the US dollar is as follows:

$$
\begin{gathered}
r_{t}=0.832002 r_{t-1}+\varepsilon_{t}-0.852280 \varepsilon_{t-1} \\
\ln \sigma_{t}^{2}=-0.690229+0.511037\left|\frac{\varepsilon_{t-1}}{\sigma_{t-1}}-E\left(\frac{\varepsilon_{t-1}}{\sigma_{t-1}}\right)\right|-0.197545 \frac{\varepsilon_{t-1}}{\sigma_{t-1}}+0.901431 \ln \sigma_{t-1}^{2}
\end{gathered}
$$

The sum of the coefficients obtained through the model is 0.524894 , which is less than 1 , indicating that the exchange rate market has continuous fluctuations. In addition, the results of the ARCH effect test on the residual (see Table 6) show that the p value is 0.382627 , which is more than 0.05 , so the residual does not have the ARCH effect. Since the coefficient of the asymmetric term is 0.511037 , which is greater than 0 , indicating that the message of the current market "bull news" is more influential than the "bear news", and illustrating that the role of the information is asymmetrical. Therefore, the "leverage effect" of the yield rate of the exchange rate of RMB against the US dollar in the current financial market is not significant.

Table 6 The ARCH effect test of EGARCH $(1,1)$ model residual error ARCH Test:

\begin{tabular}{llll}
\hline \hline F-statistic & 0.958098 & Probability & 0.384505 \\
Obs*R-squared & 1.921389 & Probability & 0.382627 \\
\hline \hline
\end{tabular}

\section{Conclusion}

This paper analyzes the volatility of the yield rate of the exchange rate of RMB against the US dollar and draws the following conclusions:

First, it can be seen from the description of the sample data of the yield rate of the exchange rate that the yield rate series of RMB against the US dollar shows the significant phenomenon of a sharp peak and a thick tail. The yield rate sequence of the exchange rate of RMB against the US dollar shows the significant characteristics of a sharp peak and a thick tail and the residual sequence of the yield rate has heteroscedasticity.

Second, in the EGARCH $(1,1)$ conditional variance equation estimation of the yield rate series of the exchange rate of RMB against the US dollar, each parameter is significantly less than 0 , which also indicates that the RMB exchange rate does have information asymmetry, that is, leverage effect. The bear news of the impact of the RMB exchange rate is greater than the bull news, and investors are 
more sensitive to bear news than bull news.

Third, in the autocorrelation test of the yield rate series of the exchange rate of RMB against the US dollar, it is found that the relationship between the exchange rate of RMB against the US dollar and its lagging terms is not significant, which indicates that the exchange rate market of RMB against the US dollar is not only effective for the market, but also has a certain degree for the effectiveness of China's exchange rate reform.

\section{References}

[1] Juan Wang. Analysis of RMB exchange rate volatility based on time series model [D]. Chengdu University of technology, 2014. In Chinese

[2] Yao Liu. Research on RMB exchange rate prediction based on ARMA model -- a case study of RMB exchange rate against us dollar [J]. Journal of langfang normal university (nature science edition), 2016, (02):53-58. In Chinese

[3] Kun Yao. Characteristic analysis and modeling of exchange rate volatility in China's foreign exchange market [D]. Shandong University, 2016. In Chinese

[4] Chen Meng. Empirical analysis on the long-term memory of RMB exchange rate volatility [D]. Jilin University, 2015. In Chinese

[5] Chi Zhang. Empirical research on RMB exchange rate based on time series analysis [J]. Journal of xuzhou institute of engineering (nature science edition), 2016, (03):58-61. In Chinese 